but possibly third or fourth, for the sake of his club or his country; or whether, he would be wiser, again in the interests of his team as well as himself, to ease the strain on his muscles, and to save himself for the next time.

Then there is the question of the man who comes back from defeat, Lachie Stewart, I think, had been written off as a long distance sprinter, he was said not to have the staying power for that final burst. But Stewart never gave up. He kept coming back from defeat, and we all saw at the Commonwealth Games in Edinburgh how he won that 10,000 metres. That was certainly courage.

There are as yet no final answers to these major questions. But perhaps again this conference will provide some. Certainly all these questions are of international interest and the number of countries represented at this Congress and the distinguished delegates we have with us bear witness to the importance in which sports medicine is held around the world.

It gives me great pleasure to declare open the 18th World Congress of Sports Medicine.

\title{
OBITUARY
}

\section{PROFESSOR PAUL CHAILLEY-BERT (1890-1973)}

It is with great regret that we announce the death of Paul Chailley-Bert, President d'Honneur of the International Federation of Sports Medicine.

Born in 1890 his medical studies were interrupted by the first World War in which he served with distinction, taking part in the epic defence of Verdun and gaining the Croix de Guerre and the Legion of Honour.

From the first he evinced a love of physiology and in 1924 took charge of the course of physiology as applied to physical education, founding the Institute of Physical Education at the University of Paris some three years later. Apart from a break when he held the Chair of Physiology at Nancy, he remained director of the Institute until he retired in 1963.

In 1926 Paul Chailley-Bert was one of the founders of the F.I.M.S. rising to become its President and finally its President d'Honneur. The doyen of Sports Medicine, Paul Chailley-Bert made singular contributions to its development especially in the field of physiology and later through his international activities. A figure of considerable presence, he displayed not only great charm and culture but also a Puckish sense of humour. In later years an Honorary Member of the B.A.S.M., he will be remembered by many for his delightful contributions to the World Congress of Sports Medicine in Oxford.

With his passing ends an era in Sports Medicine and he is deeply mourned by the many of both high and low estate to whom he so generously gave his friendship and council. 